\title{
Pengaruh Doping Litium Terhadap Intensitas Luminisens Nanopartikel Zno Menggunakan Metode Sol Gel
}

\author{
M. Ilham*, Astuti \\ Jurusan Fisika, FMIPA, Universitas Andalas, Kampus Limau Manis Padang, 25163 \\ *Ilhammuhamad77@yahoo.com
}

\begin{abstract}
ABSTRAK
Nanopartikel $\mathrm{ZnO}$ disintesis dengan metode sol-gel menggunakan $\mathrm{Li}_{2} \mathrm{CO}_{3}$ sebagai pendoping dengan variasi konsentrasi 0, 4, 6 dan 8\% mol. Hasil sintesis dikarakterisasi dengan difraksi sinar X (XRD) untuk menentukan ukuran dan stuktur kristal, sedangkan UV-Vis untuk menentukan lebar celah pita energi. Hasil XRD menunjukan bahwa stuktur kristalnya hexagonal dan ukuran kristal yang didapat adalah 28,33; 32,68; 60,69 dan 60,72 nm. Energi gap terkecil berada pada saat konsentrasi $8 \%$ mol yaitu 3,09 eV. Nanopartikel $\mathrm{ZnO}$ yang disinari lampu UV berwarna kuning.

Kata kunci: luminisen, $\mathrm{Li}_{2} \mathrm{CO}_{3}$, nanopartikel, sol gel, $\mathrm{ZnO}$
\end{abstract}

\begin{abstract}
Nanoparticle $\mathrm{ZnO}$ was synthesized by using sol-gel method with $\mathrm{Li}_{2} \mathrm{CO}_{3}$ as a dopant with consentration variations of 0, 4, 6 and $8 \%$ mol. X Ray diffraction (XRD) were used to determine crystal size and structure, while UV-Vis used to determine of energy gap. XRD patterns show that its crystal structure is hexagonal and crystalline size are 28,3; 32,68; 60,69 and 60,72 $\mathrm{nm}$ respectively. The narrowest energy gap $(3.09 \mathrm{eV})$ is found at sample with $8 \%$ mol dopant consentration. Nanoparticle $\mathrm{ZnO}$ doped $\mathrm{Li}_{2} \mathrm{CO}_{3}$ that was iluminited under UV lamp shows the yellow light.

Keywords: luminisens, $\mathrm{Li}_{2} \mathrm{CO}_{3}$, nanoparticle, sol gel, $\mathrm{ZnO}$
\end{abstract}

\section{PENDAHULUAN}

Zink oksida $(\mathrm{ZnO})$ adalah semikonduktor yang banyak dikembangkan dan diminati sebagai nanomaterial luminisens karena memiliki sifat unik, yaitu memiliki celah pita energi yang lebar dari kelompok semikonduktor II-VI. Material $\mathrm{ZnO}$ memiliki celah pita energi 3,4 eV (Abdullah, 2008), sifat ini memberikan peluang $\mathrm{ZnO}$ untuk diaplikasikan sebagai luminisens. Partikel $\mathrm{ZnO}$ dalam ukuran besar memiliki beberapa kelemahan seperti area permukaan pervolume yang kecil dan celah pita energi yang kurang sesuai apabila diaplikasikan pada cahaya tampak. Oleh karena itu, untuk mengoptimalkan sifat dari $\mathrm{ZnO}$ maka perlu dilakukan pendopingan. $\mathrm{ZnO}$ memiliki karakteristik tipe yaitu tipe-p. Material doping untuk $\mathrm{ZnO}$ tipe-p antara lain kalium (Zhang, dkk., 2011), litium, tembaga , fosfor dan arsen.

Menurut Ardyanian dan Sedigh (2013) ZnO yang didoping litium dapat menurunkan celah pita energi. Celah pita energi yang semakin kecil, menyebabkan semakin mudahnya eksitasi elektron dari pita valensi ke pita konduksi (Ningsih, 2012). Penelitian ini akan dikembangkan material luminisens dari $\mathrm{ZnO}$ yang didoping dengan litium, dengan menggunakan metode sol gel. Metode ini memiliki kelebihan seperti mudah dalam kontrol komposisi (kehomogenan komposisi kimia baik), temperatur proses rendah dan biaya murah. Pada penelitian ini juga akan dilakukan optimasi kosentrasi litium, sehingga diperoleh material dengan luminisens stabil dan intensitas luminisens tinggi sampai rentang panjang gelombang cahaya tampak. Karakteristik yang dilakukan untuk mengetahui ukuran dan struktur kristal digunakan dengan karakterisitik X-Ray difraction (XRD) dan UV-Vis Spectrometry digunakan untuk menentukan celah pita energinya.

\section{METODE}

\subsection{Sintesis koloid nanopartikel}

Sintesis nonopartikel $\mathrm{ZnO}$ dilakukan dengan metode sol-gel. Pada metode ini koloid $\mathrm{ZnO}$ disintesis dalam larutan etanol $96 \%$ dan $\mathrm{LiOH} . \mathrm{H}_{2} \mathrm{O}$ sebagai agen hidrolisisnya. Zink asetat dihidrat $\left\{\mathrm{Zn}\left(\mathrm{CH}_{3} \mathrm{COOH}\right)_{2} \cdot 2 \mathrm{H}_{2} \mathrm{O}\right\}$ sebanyak $1 \mathrm{~g}$ dilarutkan dalam $42 \mathrm{~mL}$ etanol, setelah itu diaduk menggunakan magnetic stirrer dan dipanaskan pada suhu $65^{\circ} \mathrm{C}$ selama 30 menit. Secara terpisah litium hidroksida monohidrat $\left(\mathrm{LiOH} . \mathrm{H}_{2} \mathrm{O}\right)$ berat $0,28 \mathrm{~g}$ dicampur dengan $23 \mathrm{~mL}$ etanol 
dalam ultrasonic bath selama 16 menit hingga diperoleh larutan homogen.

Pendopingananyadisiapkan terlebih dahulu yaitu $\mathrm{Li}_{2} \mathrm{CO}_{3}$.

Selanjutnya, larutan $\mathrm{Zn}\left(\mathrm{CH}_{3} \mathrm{COOH}\right)_{2} \cdot 2 \mathrm{H}_{2} \mathrm{O}$ dan $\mathrm{LiOH} . \mathrm{H}_{2} \mathrm{O}$ dicampur disertai dengan penambahan senyawa $\mathrm{Li}_{2} \mathrm{CO}_{3}$ berdasarkan variasi konsentrasi yaitu $0,4,6$ dan $8 \%$ mol sebagai pendopingnya menggunakan magnetic stirrer dengan suhu $65^{\circ} \mathrm{C}$ sampai larutan berubah menjadi warna putih susu. Larutan ini sudah terbentuk dalam sol. Selanjutnya dilakukan proses ageing (pematangan) selama satu hari. Setelah itu, untuk mendapatkan $\mathrm{ZnO}$ dalam bentuk gel dilakukan sentrifugasi $4000 \mathrm{rpm}$ selama 10 menit. $\mathrm{ZnO}$ dalam bentuk gel akan dipanaskan pada suhu $140^{\circ} \mathrm{C}$ selama 1 jam untuk memperoleh serbuk $\mathrm{ZnO}$.

\subsection{Karakterisasi}

\subsubsection{X-Ray Diffractions}

Data output dari XRD yang disebut sebagai difraktogram dianalisis dengan membandingkannya dengan dengan pola difraksi standar yang terdapat pada data International Center for Diffraction Database (ICDD) dalam Powder Diffraction File (PDF). Ukuran kristal $\mathrm{ZnO}$ didapatkan dari persamaan Scherrer seperti ditunjukan oleh Persamaan 1.

$$
D=\frac{K \lambda}{B \cos \theta}
$$

$D$ adalah ukuran kristal, $K$ adalah nilai konstanta , $\lambda$ adalah panjang gelombang radiasi sinar-X, $B$ adalah lebar penuh garis difraksi pada saat intensitas setengah maksimum dan $\theta$ adalah sudut Bragg. Sampel yang digunakan untuk analisis XRD berbentuk serbuk (powder).

\subsubsection{UV-Vis spectrometry}

Uv-Vis Spectrometry berguna untuk menentukan lebar celah pita energi. Dasar pemikiran metode ini adalah jika mateial di sini dengan gelombang elektromagnetik maka foton akan diserap oleh elekton dalam material. Setelah menyerap foton, elektron akan berusaha meloncat ke tingkat energi yang lebih tinggi. Penentuan nilai energi celah pita optik dianalisis menggunakan metode Toucplot. Metode ini ditentukan dengan menarik ekstrapolasi pada daerah linier dari grafik hubungan $h v$ dan $(A h v)^{2}$ hingga memotong sumbu energi $(h v)$.

\section{HASIL DAN DISKUSI}

\subsection{Hasil XRD}

Pengamatan struktur kristal dan fasa yang terbentuk dalam material $\mathrm{ZnO}$ yang didoping dengan Litium karbonat dengan variasi konsentrasi 0, 4, 6 dan 8\% mol dilakukan menggunakan X-Ray Diffraction (XRD). Hasil karakteristik tersebut dicocokan dengan data ICDD dalam PDF (Powder Diffraction file) dan dapat dilihat pada Gambar 1.

Dari hasil XRD diketahui partikel $\mathrm{ZnO}$ yang didoping dengan litium memiliki stuktur kristal hexagonal. Variasi konsentrasi doping $\mathrm{Li}_{2} \mathrm{CO}_{3} \quad 0,4,6$ dan $8 \%$ mol menghasilkan ukuran kristal berturut-turut 28,$33 ; 32,68 ; 60,69$; dan 60,72 nm. Semakin besar persentase doping Li maka ukuran kristal akan semakin besar karena adanya distorsi (penyimpangan) regangan pada kisi selain itu juga dipengaruhi oleh banyaknya difusi ion litium serta banyaknya intersisi $\mathrm{Zn}$ dan kekosongan O pada kisi ZnO (Rakers dan Balakumar, 2014). 


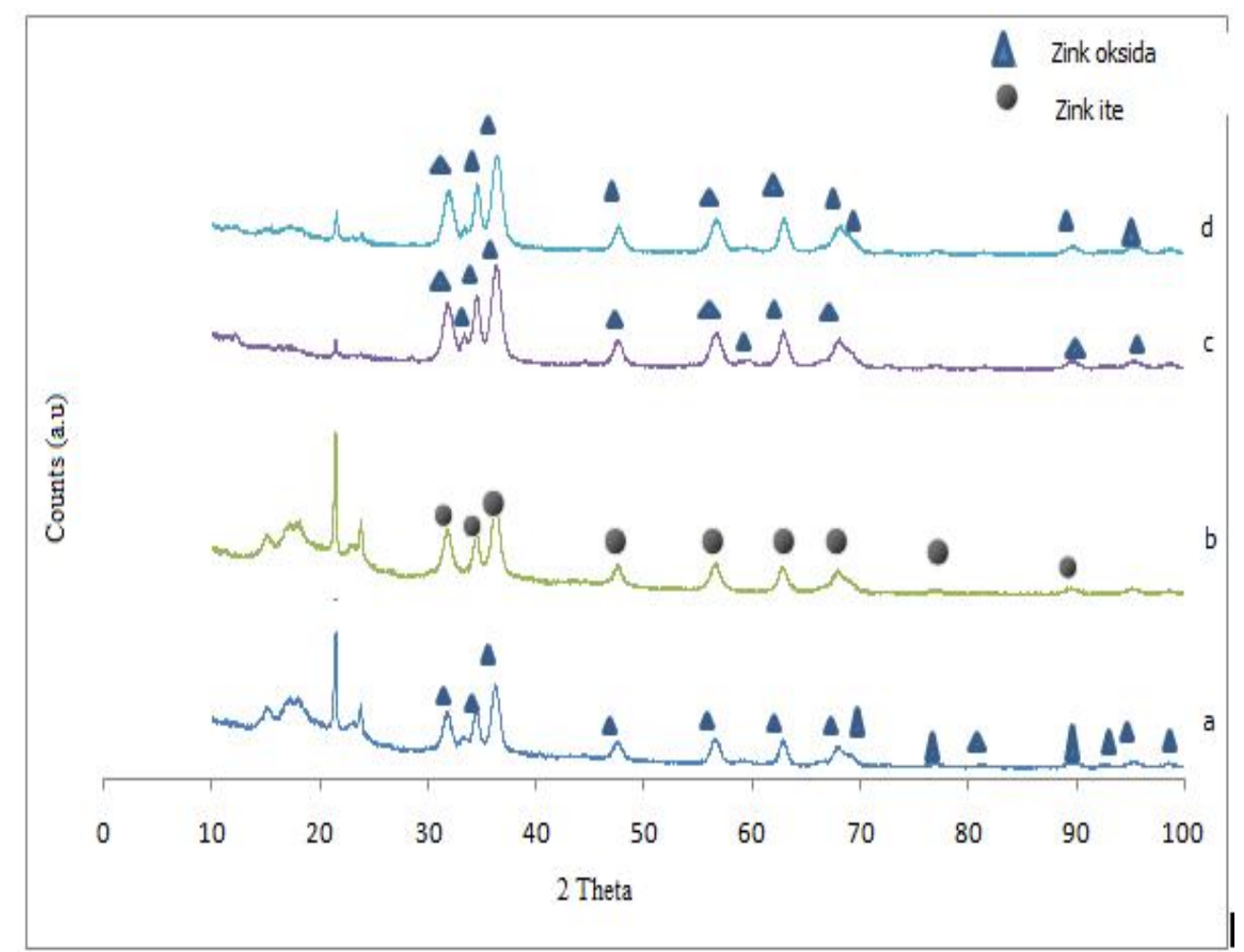

Gambar 1 Hasil uji XRD pada sampel ZnO doping Li dengan variasi kosentrasi (a) 0\%, (b) $4 \%$, (c) $6 \%$ dan (d) $8 \%$ mol.

\subsection{Hasil $U V$-Vis Spectrometry}

Hasil sintesis nanopartikel selanjutnya akan dikarakterisitk dengan UV-Vis Spectrometry untuk menentukan celah pita. Berdasarkan data UV-Vis Spectrometry diperoleh panjang gelombang $(\lambda)$ terhadap absorbansi. Spektrum transmisi yang diperoleh diolah menggunakan metode Touch Plot untuk mendapatkan celah pita energi. Tabel 1 menunjukan nilai energi gap dengan adanya variasi konsentrasi Li.

Tabel 1 Celah pita energi

\begin{tabular}{cc}
\hline Variasi konsentrasi Li $(\% \mathbf{~ m o l})$ & Energi gap $(\mathbf{E v})$ \\
\hline $0 \%$ & 3,24 \\
$4 \%$ & 3,19 \\
$6 \%$ & 3,15 \\
$8 \%$ & 3,09
\end{tabular}

Tabel 1 menunjukan bahwa kenaikan konsentrasi $\mathrm{Li}_{2} \mathrm{CO}_{3}$ menyebabkan celah pita energi semakin kecil karena memiliki energi ionisasi yang semakin berkurang dari unsur lain terutama pada golongan IA. Penurunan energi ionisasi disebabkan penambahan jari-jari atom, sehingga gaya tarik-menarik inti dengan elektron valensi semakin lemah, dan keelektronegatifan semakin berkurang. Kecendrungan ini juga disebabkan penambahan jari-jari atom, sehingga melemahkan gaya tarik inti. Oleh sebab itu litium sering digunakan sebagai doping pada material luminisens supaya mendapatkan celah pita energi yang semakin kecil untuk aplikasi yang lebih luas baik dalam bidang optik maupun optoelektronika.

\section{KESIMPULAN}

Pengujian karakterisasi menggunakan XRD dengan variasi konsentrasi doping $\mathrm{Li}_{2} \mathrm{CO}_{3}$. Semakin besar persentase doping Li maka ukuran kristal akan semakin besar. Ukuran kristal terkecil diperoleh $\mathrm{Li}_{2} \mathrm{CO}_{3}$ tanpa doping. Stuktur $\mathrm{ZnO}$ kristalnya adalah hexagonal. Sedangkan $\mathrm{UV}-\mathrm{Vis}$ menunjukan bahwa penambahan konsentrasi $\mathrm{Li}_{2} \mathrm{CO}_{3}$ menyebabkan terjadinya penurunan energi gap. Energi gap terkecil diperoleh pada konsentrasi $\mathrm{Li}_{2} \mathrm{CO}_{3} 8 \%$ yaitu 3,09 eV. 


\section{DAFTAR PUSTAKA}

Abdullah, M., Pengantar Nanosains (Institut Teknologi Bandung, Bandung, 2008), hal 4-10.

Ardyanian, M. dan Sedigh, N.,"Heavy Lithium Doped ZnO Thin Films Prepared by Spray Pyrolysis Method", Skripsi S1, Damghan University, 2013.

Ningsih, T.S, "Sintesis dan Karakteristik Fotokatalis ZnO Berbasis Zeolit Alam", Skripsi S1, Universitas Indonesia, 2012.

Rakkesh, R.A., Balakumar, S, Journal of Ceramics. 8, 7-13 (2014).

Zhang, L., Ye, Z., Huang, J., Lu, B., He, H., Lu, J., Journal of Alloys and Compounds. 509, 7405-740 (2011). 